症例

右眼球突出を初発症状とした腸間膜原発悪性リンパ腫の 1 例

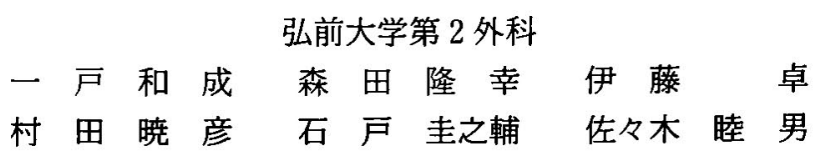

眼球突出を初発症状とした小腸間膜原発悪性リンパ腫の 1 例を経験した.

症例は 52 歳, 女性. 右眼球突出を自覚. 精査の結果, 右眼窝腫瘍と腹部腫瘍を指摘さ れた。腹部 CT で, 膵体部下縁の高さから下方へ約 $8 \mathrm{~cm}$ の腫瘍を腹腔内に認め, $\mathrm{Ga} シ$ ンチでは胸椎, 肋骨にも hot lesion を認めた。 その後腹部腫愓の増大による腸閉塞症状 が出現し, 手術を施行した。腫瘍は空腸間膜に発育しており, 病理組織学的診断は悪性 リンパ腫（Non-Hodgkin's malignant lymphoma, diffuse, large cell, B-cell type) で あった。術後, 全身化学療法 (CHOP), 骨転移巣に $30 \mathrm{~Gy}$ の放射線照射施行し眼球突出 の軽快をみたが, その後腫瘍の増大を認め, 術後約 9 力月目に死亡した. 本症例では腸 閉塞により手術施行を余儀なくされたが，術前に眼䆟腫瘍の組織診断がなされ病期診断 が下されていれば，患者に対し侵襲の少ない治療法を選択することが可能であったと考 えられた。

索引用語：腸間膜悪性リンパ腫, 眼球突出, 眼窩内転移

\section{緒 言}

腸間膜原発悪性リンパ腫は全悪性リンパ腫中 0.12 \% ${ }^{11}$ と極めて稀で，予後不良な疾患である.今回われわ れは, 右眼球突出を初発症状とした小腸間膜原発悪性 リンパ腫の 1 例を経験したので報告する.

\section{症 例}

患者：52歳, 女性.

主訴: 右眼球突出.

現病歴: 平成 9 年 10 月より右眼球突出を自覚. 精査 にて右眼窩腫瘍および腹部腫崵を指摘された。経過中 に腹痛があり，腫㪦による腸閉塞の診断にて手術目的 に平成10年 1 月 5 日当科入院となった。

既往歴：10年前, 非特異性大腸炎にて加療.

家族歴：父親が大腸癌, 母親が胃癌で死亡.

入院時現症：右眼球の突出が認められた（図 1 a). 左上腹部に超手拳大, 表面に凹凸のある硬い腫瘤が触 知された.

入院時検査成績: 生化学検査で血清 LDH 值が305

2001 年 4 月 5 日受付 2001 年 7 月11日採用

〈所属施設住所〉

厂036-8562 弘前市在府町 5
$\mathrm{U} / 1$ と上昇を認めた。また腫瘍マーカーでは CA125が $99 \mathrm{U} / \mathrm{ml}$ と上昇していた。

腹部超音波検査：膵体部下緑の高さから左堅下極の

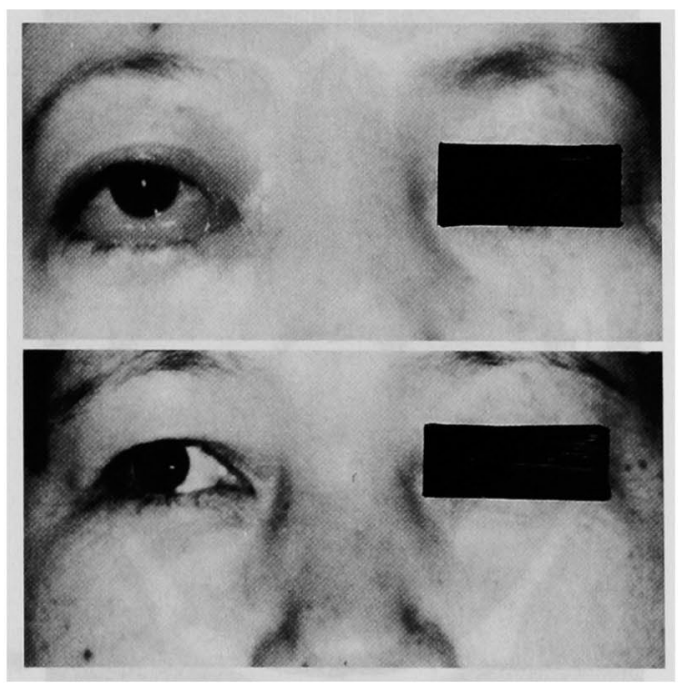

図 $1 \mathrm{a}$ 術前：右眼球突出と眼球結膜の充血を認め た.

b 加療後：右眼球突出は改善した。 
高さの腹腔内に境界が比較的明瞭で内部エコーが不均

一な腫瘤性病変を認めた。

注腸造影：横行結腸に腫瘍による圧排像を認めた が, 狭窄，浸潤像は認めなかった。

腹部造影 $\mathrm{CT}$ 検査 : 膵体部下縁の高さから長径約 8 $\mathrm{cm}$ の腫瘍を腹腔内に認めた. 小腸の拡張像も認めた

(図 2 ).

頭部 MRI : 右眼窝, 眼球後部の筋円錐内に $40 \times 34$ $\mathrm{mm}$ の腫瘍を認め, 外眼筋の圧排を認めた。視神経は 腫崵に取り曲まれ高度の狭窄を呈していた（図 3 )。

$\mathrm{Ga}$ シンチグラフィー：腹部腫場に一致した部位と

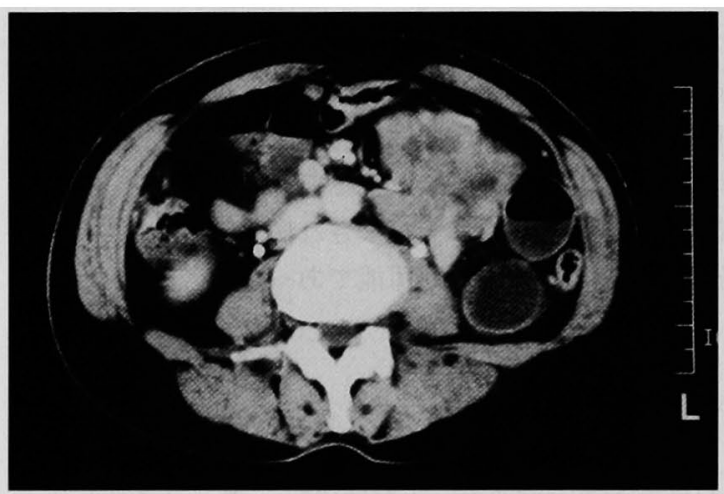

図 2 腹部造影 CT：膵体部下緑の高さから長径約 $8 \mathrm{~cm}$ の腫煌を腹腔内に認めた。

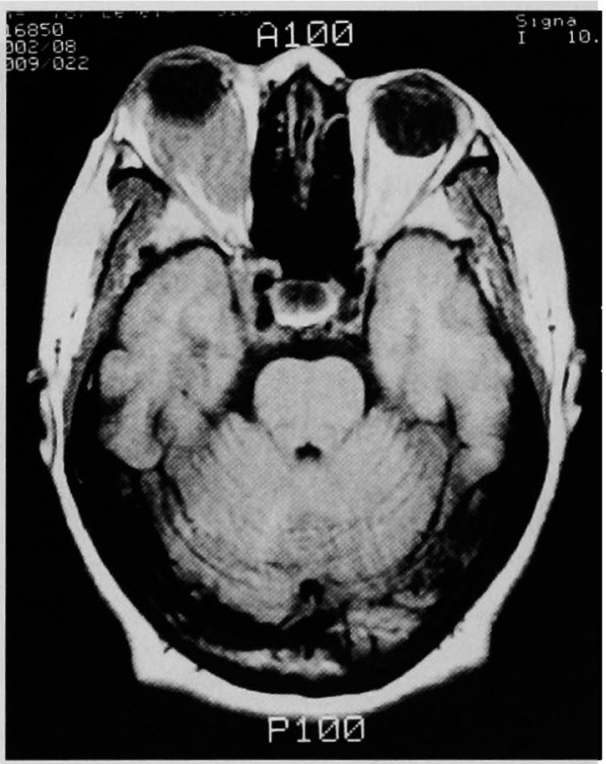

図 3 頭部 MRI：右眼裔筋円錐内に腫奭を認め た.
第 8 胸椎, 右肋骨に $\mathrm{Ga}$ の蓄積による hot lesionを めた。右眼窩には集積像は認めなかった（图 4).

腹部血管造影：空腸上部に分布する血管新生がみ れたが、明らかな腫場濃染像は認めなかった。

以上から, 腹腔内腫惶 (悪性リンパ腫疑い) と診 したが腸閉塞症状が悪化したため, 平成10年 1 月 27 開腹手術を施行した。

手術所見：腫場はトライツ靶帯直下の空腸間膜に 育し, 上腸間膜動脈の腹側で大網に軽度癒着し小児 拳大の腫瓷を形成していた。第 $1 \sim 3$ 空腸動脈を巻 込み発育していたためこれを切離，結势し空腸とと に摘出した。術中迅速凍結標本では類円形の核を有 る異形成の細胞が diffuse に堌殖し, 悪性リンパ腫 強く疑われた。

切除標本：腫場は表面に凹凸があり, $9.5 \times 7.5 \times 5$ $\mathrm{cm}$ であった. 切除した空腸は約 $50 \mathrm{~cm}$, 空腸壁に直 浸潤は認めなかった（図５）。

病理組織学的所見：類円形の核を有する大型の異 細胞の diffuse な増殖を認め, Non-Hodgkin's mali nant lymphoma, diffuse, large cell, B-cell type $と$ 断された（図 6 ).

術啳経過：術後全身化学療法 (CHOP) を6クー

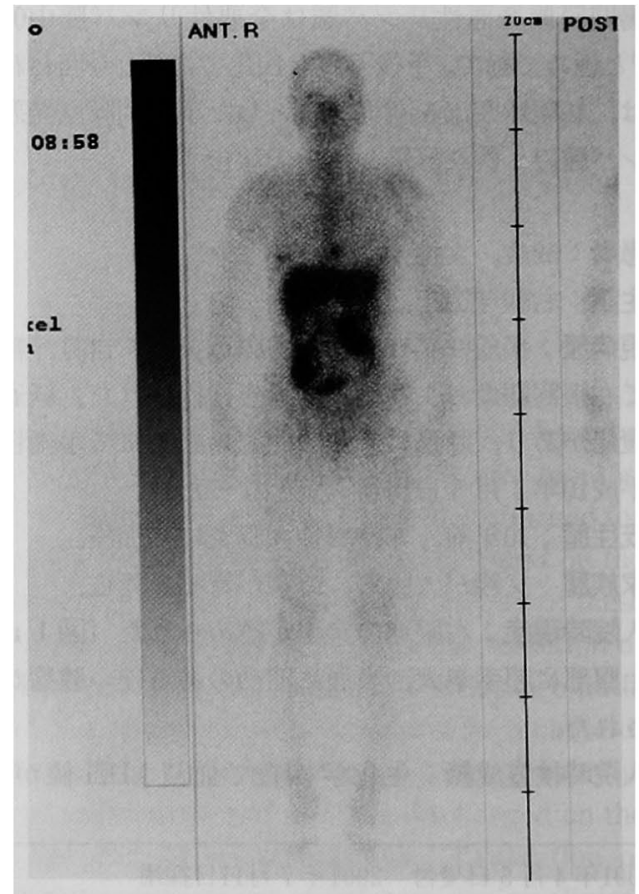

図 $4 \mathrm{Ga}$ シンチ：腹部腫崵, 第 8 胸椎, 右助骨に hot lesion. 右眼窩には集積像は認めなかった。 
施行し, 眼球突出は軽快した (図 1 b) . 骨転移巣に対 して合計30Gy の放射線療法も施行した. CHOP の 6 クール目までは, 悪性リンパ腫の経過観察に有用なマ 一カーの 1 つである LDH 值は正常域を推移し, 画像 上も病状進行を示す所見は認めなかった。しかし平成 10 年 7 月後半に LDH 值が上昇したため精查したとこ 了, 多発性肝転移, 腹腔内再発を認め, その後病状は 悪化し，平成10年10月24日死の転帰をとった（図 7 ).

\section{考察}

原発性腸間膜腫場の頻度は $0.00018 \sim 0.012 \%{ }^{2)}$ であ り，また腸間膜原発悪性リンパ腫は村山ら”の報告に よると，全悪性リンパ腫中 $0.12 \%$ と極めて稀な疾患で

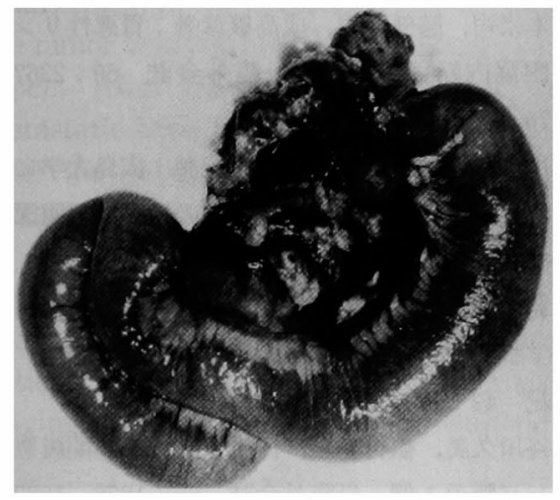

図 5 切除標本：腫瘍の表面には山凸を認めた $(9.5 \times$ $7.5 \times 5.2 \mathrm{~cm})$ ，空腸への直接浸潤は認めなかった。
ある、また，腸間膜腫瘍に特有な臨床症状は認められ ず，多くは腹部腫瘤の触知として発見される ${ }^{3)}$.

これに対し，本症例は，転移性の眼窩腫瘤による右 眼球突出を初発症状としている. 眼窩腫瘍の発生頻度 は高見ら ${ }^{4)}$ の報告によると0.133\%であり，その中でも 覀性リンパ腫の眼窩転移は $2.3^{4)} \sim 6.7 \%^{5)}$ と極めて稀 で, 現在まで本例を含めて, 本邦では腹部悪性リンパ 腫の眼窩転移は 3 例の報告6)7を見るのみである. 眼窩 腫瘍の診断については，発病から眼科受診までの期間 が短いこと, 眼球突出が著しい等の臨床所見 ${ }^{8)}$, また $\mathrm{CT}, \mathrm{MRI}$ 等の検査での骨破壊像や外眼筋の肥厚所見 等から悪性腫瘍を疑うことは可能であるとされる ${ }^{4}$.

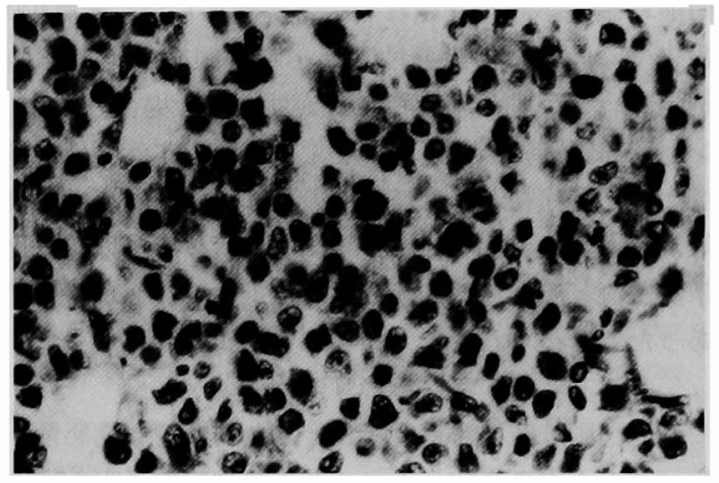

図 6 病理組織像：類円形の核を有する大型の異型細胞 の diffuse な增殖を認めた $(\mathrm{HE}: \times 400)$.

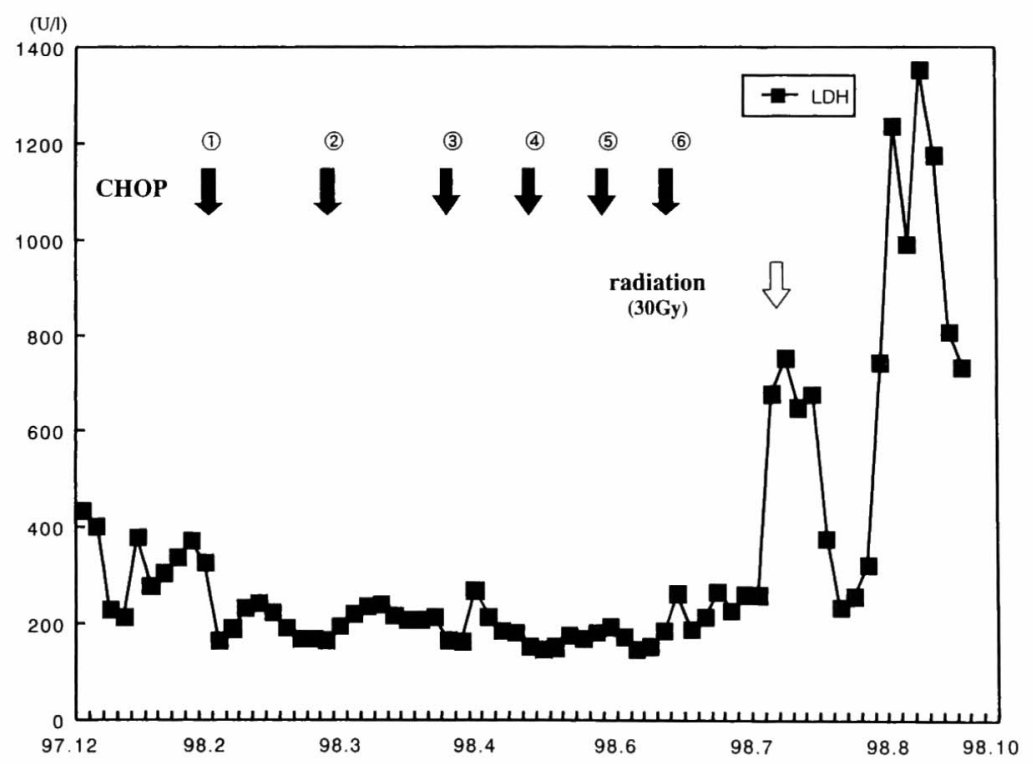

図 7 LDH 值：化学, 放射線療法を施行したものの, 術後 7 力月後頃より上昇した. 
しかし質的診断には不十分であり，最終的には吸引細 胞診を施行し，上記の検查結果を含めた検討が必要で あるが9), 解剖学的な難しさから生検を施行できる例 は少ない5)。

文献上, 眼简転移が認められるような, 進行期の悪 性リンパ腫の予後は極めて不良であり，1年以上の生 存を認めている報告は極めて稀である(1011)．自験例に おいても, Ann Arbor 分類のIV期で術後早期から化学 療法，放射線療法を施行したものの不幸な転帰をたど った.

腸間膜原発悪性リンパ腫の進行例では，外科的手術 にのみ頼ることなく，化学療法や放射線療法を組み合 わせて治療を行うことが重要である゙2.そのためには 術前に確定診断がなされることが望ましい。後藤5の 報告や，藤本らの胃悪性リンパ腫の眼窩転移の報告 例》によれば，眼滈腫瘍の存在が明らかな場合，要性り ンパ腫の眼窩転移も疑うべきとされる．本症例は眼球 突出を初発症状とした進行例のため, 眼窝腫瘍の生検 等が施行できれば本症例は腸閉塞症状の出現以前に化 学療法などの非侵襲的な治療を選択することが可能て あったと考えられた。

おわりに

今回, 眼球突出を初発症状とした腸間膜原発悪性り ンパ腫の 1 例を経験したので若干の文献的考察を加え て報告した。

\section{文 献}

1）村山直弘, 荒井保明，青木 誠他：腸間膜原発と 考えられる悪性リンパ腫の 2 例. 医療 $36: 41-$ 47,1982
2）浅井貞宏，鬼塚康徳，谷岡 一他：腸間膜悪性り ンパ腫. 別冊日本臨床, 領域別症候群シリース, No11. 日本臨床社, 東京, 1996, p146-148

3）松本浩次，渡辺 心，児島邦明他：腸間膜原発悪 性リンパ腫の 1 例.日臨外会誌 $60 ： 3015-3018$, 1999

4）高見淳也，小松大記，林 啺紹他：高知医科大学 過去16年間におりる眼窩腪原 43 例の統計的倠察. 臨眼 $94: 137-141,2000$

5）後藤 浩：眼窝転移. 眼科 $42: 167-174,2000$

6）船津英陽，山下英俊，啮谷 彰他：化学療法に上 り視力改善をみた悪性リンパ厙眼窝内転移の 1 例。あたらしい眼科 $6: 1073-1077,1989$

7）藤本崇司，勝部隆男，成高義彦他：胃悪性リンパ 腫眼窝内転移の 1 例. 日臨外会誌 $60 ： 2367-$ 2370,1999

8）梶川 哲, 三嶋 弘, 二井宏紀他：広島大学にお ける最近 11 年間の眼窝腫境52例の検討。眼臨医報 $89: 441-445,1995$

9）早見宏之，山下 泉，将野俊哉他：富山医科薬科 大学眼科における眼窩腫境70例の統計的観察. 日 眼紀 42:1449-1457，1991

10）長谷川久美，植竹宏之，河原寞人他：腸間膜悪性 リンパ腫の 1 例。日臨外会誌 $58: 1878-1882$, 1997

11）吉田秀明，枝澤 寛，野納邦昭他：CHOP 療法て 2 年以上 $\mathrm{CR}$ を得ている巨大腸間膜原発悪性リン ハ腄の 1 例。日消外会誌 $33 ： 1925-1929 ， 1999$ 


\title{
A CASE OF MALIGNANT LYMPHOMA OF THE MESENTERIUM PRESENTED WITH RIGHT EXOPHTHALMOS
}

\author{
Kazushige ICHINOHE, Takayuki MORITA, Takashi ITOH, Akihiko MURATA, \\ Keinosuke ISHIDO and Mutsuo SASAKI \\ Second Department of Surgery, Hirosaki University School of Medicine
}

We have encountered a case of malignant lymphoma of the mesenterium presented with right exophthalmos.

A 52-year-old woman noticed right exophthalmos two months earlier. Computed tomography (CT) revealed a right orbital tumor and an upper abdominal tumor $8 \mathrm{~cm}$ in diameter. The abdominal tumor was revealed as hot area of RI uptake on a $\mathrm{Ga}^{67}$ scintigram, and was considered as malignant tumor. On January 5 1998, she had severe, burning epigastric pain, abdominal distension and vomiting due to an enlargement of the abdominal tumor. Emergency operation was performed and about $50 \mathrm{~cm}$ jejunum with the tumor was resected. Histological examination confirmed malignant lymphoma (diffuse, large, B-cell type). After the operation, systemic chemotherapy with 6 cycles of $\mathrm{CHOP}$ and radiotherapy for metastatic bone tumor at $30 \mathrm{~Gy}$ were given and a transient remission was attained. However, 9 month after the initial operation, the patient's condition took a downhill course and died of multiple liver metastasis.

It is extremely difficult to diagnose malignant lymphoma of the mesenterium. When the tumor is detected, many cases are of far advanced. Early diagnosis and systemic radiochemotherapy should be adapted to improve the poor prognosis of this disease. In this case, we had to operate on because the patient had developed intestinal obstruction. However, with preoperative histologic study and clinical staging, less invasive therapeutic method might be selected. 